\title{
On the effect of saline immersion to the removal torque for resorbable blasting media and acid treated implants
}

\author{
Jae-uk Kwon, Sung-am Cho* \\ Department of Prosthodontics, College of Dentistry, Kyung-pook National University, Daegu, Republic of Korea
}

\begin{abstract}
Purpose: The purpose of this study is to investigate the effect of the titanium implant soaked in saline after RBM and acid etched surface treatment on the initial osseointegration by comparing the removal torque and the surface analysis compared to the titanium implant with only RBM and acid etched surface treatment. Materials and Methods: The control group was RBM and acid etched surface treated implants (RBM $+\mathrm{HCl})$, and the test group was implants soaked in saline for 2 weeks after RBM and acid etched surface treatment ( $\mathrm{RBM}+\mathrm{HCl}+\mathrm{Sal})$. The control and test group implants were placed in the left and right tibiae of 10 rabbits, respectively, and at the same time, the insertion torque (ITQ) was measured. After 10 days, the removal torque (RTQ) was measured by exposing the implant site. FE-SEM, EDS, Surface roughness and Raman spectroscopy were performed for the surface analysis of the new implant specimens used in the experiments. Results: There was significant difference in insertion torque and removal torque between control group and experimental group $(P=0.014<0.05)$. Surface roughness of experimental group is higher than control group. Conclusion: Saline soaking after RBM and acid etched surface treatment of titanium implants were positively affect the initial osseointegration as compared to titanium implants with only RBM and acid etched surface treatment. (J Dent Rehabil Appl Sci 2018;34(1):1-9)
\end{abstract}

Key words: implant; hydroxyapatites; acid etching; sodium chloride; rabbits

\section{서론}

무치악 부위의 수복에 널리 이용되고 있는 임플란트는 현대 치의학에서 없어서는 안될 중요한 치료수단의 하나 로 자리매김하고 있다. 현재까지 다양한 종류의 임플란 트들이 출시되었고 앞으로도 그 발전방향은 무궁무진할 것으로 기대되고 있다. 이러한 임플란트들의 종류를 결 정하는 인자 중 모양과 형태도 있겠지만, 임플란트의 표 면처리방식 또한 중요한 요소 중 하나이다. 왜냐하면 임 플란트의 표면처리가 골유착에 중요한 요소이며, 이것 이 골-임플란트 계면에서 골형성에 영향을 미치기 때문 이다. ${ }^{1}$ 이러한 임플란트의 표면처리방식은 크게 세가지

*Correspondence to: Sung-am Cho

Professor, Department of Prosthodontics, School of Dentistry, Kyung-pook National University, 2175, Dalgubeol-daero, Jung-gu, 41940, Daegu, Republic of Korea Tel: +82-53-600-7672, Fax: +82-53-427-0778, E-mail: sungamcho@gmail.com Received: July 29, 2017/Last Revision: August 21, 2017/Accepted: August 23, 2017
\end{abstract}

로 분류해볼 수 있는데, 첨가방식(addition technique), 삭제방식(subtraction technique), 변형방식(surface modifications)으로 나뉜다. ${ }^{2}$ 이러한 표면처리방식은 결 국 임플란트 표면의 표면에너지와 젖음성을 변화시키게 되고 표면에 다양한 단백질의 결합에 영향을 미치게 된 다. ${ }^{3}$ 임플란트의 표면처리는 결국 골유착을 향상시키는 중요한 요소이고, 그 중 표면 거칠기를 증가시키는 것이 가장 효과적이라는 보고가 있다. ${ }^{4}$ Copper 에 의하면 순 수한 티타늄임플란트의 표면거칠기를 증가시키게 되면 골과 임플란트 계면에서 골유도 및 골형성 인자들이 증 가하여 골유착을 향상시키는 것으로 보고한 바 있다. ${ }^{5}$

본 실험은 다양한 표면처리방식들 중에서 삭제방식 
에 초점을 두었다. 이는 비교적 처리방식이 간단하고 현 재 대중적으로 많이 쓰이고 있는 sandblasting, 산처리, sandblasted-large grit-acid etching (SLA) 등을 포함하는 처리방식이기 때문이다. Sandblasting방식은 산화알루미 늄, 강석(corundum), 인산칼슘이나 이산화티타늄 등의 분사입자를 티타늄 임플란트의 표면에 강한 압력으로 분 사하여 표면을 거칠게 만드는 방식이다. ${ }^{6}$ 하지만 산화알 루미늄을 사용할 경우 임플란트 표면에 잔류한 입자들이 소독과정을 거친 후에도 제거되지 않고 남아있어 잠재적 으로 조직에 유해한 요소로 작용하며, 결과적으로 골유 착을 방해하는 것으로 보고된 바 있다. ${ }^{7.8}$ 이러한 이유로 임플란트 표면에 잔류하여도 골반응에 영향을 주지 않는 이산화티타늄이나 인산칼슘을 사용하게 되었고, 특히 인 산칼슘의 경우 높은 골유도성과 생체흡수성을 가지는 것 으로 알려져 있다. 인산칼슘을 이용한 RBM (resorbable blasting media) 표면처리의 경우 다른 분사입자에 비해 높은 골-임플란트 결합(bone to implant contact)을 보 여 골유착에 유리한 작용을 하는 것으로 보고된 바도 있 다. ${ }^{9,10}$ 또한 산처리방식은 임플란트 표면에 $0.5-2.0 \mu \mathrm{m}$ 의 다양한 크기의 구멍을 형성하여, 임플란트와 섬유소 (fibrin) 및 이에 접착하는 세포들 사이에 강한 결합력을 제공하는 것으로 알려져 있다. ${ }^{11}$ 하지만 임플란트 표면처 리 시 산처리만 시행한 경우 sandblasting에 비해서 낮은 표면거칠기를 보였다는 보고가 있다. ${ }^{12}$ 앞서 임플란트의 표면처리방식은 표면의 젖음성에도 영향을 미친다고 언 급한 바 있다. 이러한 젖음성을 증가시키는 방법 중에 하 나로 표면처리 후 생리식염수에 적시는 방법이 있으며, 이는 임플란트 표면의 친수성을 향상시켜 골유착에 도움 을 주는 다양한 세포들의 부착을 도와 골형성을 촉진시 키는 것으로 알려져있다. ${ }^{13}$

이에 본 실험은 티타늄 임플란트에 앞서 언급했던 $\mathrm{RBM}$ 표면처리 및 산처리 후 생리식염수에 적신 임플란 트의 골결합력을 비교하여 임상적으로 초기에 안정적 인 골유착에 도움이 되는지를 알아보고자 한다. 따라서 $\mathrm{RBM}$ 표면처리 후 산처리한 임플란트와 RBM 표면처리 후 산처리 및 생리식염수에 적신 임플란트의 10 일 후 제 거회전력을 측정하여 초기 골결합력을 비교하여, 두 그 룹간에 제거회전력에는 차이가 없다는 귀무가설 하에 실 험을 진행하였다. 이와 더불어 임플란트의 표면분석을 통해 두 임플란트 표면처리 방식의 차이점에 대해서 비 교해보고자 하였다.

\section{연구 재료 및 방법}

\section{1. 임플란트 고정체 준비}

사용되는 티타늄 임플란트는 토끼의 경골에 식립하기 위해 commercial titanium grade 4 를 사용하여 직경 3.3 $\mathrm{mm}$, 길이 $8.0 \mathrm{~mm}$ 로 선반작업을 통해서 동일한 크기로 준비하였다. RBM 표면처리는 티타늄 임플란트를 분사 기에 고정하여 RBM (주성분이 hydroxyapitite이고, 그 외 에 tri-calcium phosphate 등을 포함)을 표면에 분사하여 준비하였다. 그 후 산처리는 염산 $(\mathrm{HCl})$ 을 이용하였으며, 증류수로 세척 후에 이소프로필알콜(isopropyl alcohol) 및 에탄올(ethanol)로 초음파 세척을 시행하였다. 마지막 으로 증류수로 다시 한번 세척을 마친 후 건열멸균기를 사용하여 멸균 처리하였고, 멸균실에서 개별적으로 진공 포장하여 준비하였다. 생리식염수에 적신 임플란트의 경 우 위와 동일한 과정으로 임플란트 표면처리 후에 생리 식염수 용액이 담긴 앰플에 넣은 것으로, 실험 2주 전에 제작하여 준비하였다.

- 대조군 : RBM 표면처리 후 산처리한 임플란트(이하 $\mathrm{RBM}+\mathrm{HCl})$

- 실험군 : RBM 표면처리 후 산처리하여 생리식염수 에 적신 임플란트 $($ 이하 $\mathrm{RBM}+\mathrm{HCl}+\mathrm{Sal})$

\section{2. 토끼 실험 준비}

평균 몸무게 $3.3 \mathrm{~kg}$ 의 암컷 뉴질랜드산 흰토끼 10 마 리를 실험에 사용하였다. 이번 실험은 The Animal Care and Use Committee of Kyung-Pook National University의 승인 후 진행되었다(KNU 2017-0098). 토끼는 $0.2 \mathrm{~mL} / \mathrm{kg}$ 의 Tiletamine/Zolazepam (Zoletil, Virbac Laboratories, Carros, France)와 $0.25 \mathrm{~mL} / \mathrm{kg}$ 의 Xylazine (Rompun, Bayer Korea, Seoul, Korea)를 사용하여 근육 주사를 통해 전신마취 하에 실험하였다.

\section{3. 수술절차}

수술 부위의 털을 제거한 후 피부 절개 전에 수술 부위 를 iodine과 75\% ethanol hybrid solution으로 소독한 후 $2 \%$ 리도카인을 이용하여 수술부위를 국소마취 하였다. 토끼의 경골부위를 절개한 후 피판을 거상하고, 가이드 드릴을 사용하여 식립위치를 형성한 후, 직경 $3.0 \mathrm{~mm}$ 드 
릴을 사용하여 $800 \mathrm{rpm}$ 속도로 임플란트 고정체 식립을 위한 구멍을 형성하였다. 드릴 시에 경골의 양측 피질골 이 천공되지 않도록 주의하였다. 오른쪽 경골에는 대조 군인 RBM $+\mathrm{HCl}$ 임플란트를 생리식염수 주수 하에 식 립하였고, 식립 시 식립회전력(insertion torque, ITQ)을 측정하기 위하여 torque gauge (MGT-12 digital torque gauge; Mark-10 Corp, New York, USA)를 사용하였 다. 왼쪽 경골에는 실험군인 $\mathrm{RBM}+\mathrm{HCl}+\mathrm{Sal}$ 임플란 트를 대조군과 동일한 방법으로 식립하면서 식립회전력 을 측정하였다. 식립 후에는 4-0 Vicryl and 3-0 Silk를 사 용하여 골막봉합 및 피부봉합을 시행하였다. 수술 후 수 술부위 소독 및 항생제를 도포하였고, $1.0 \mathrm{~mL}$ 의 항생제 (Baytril, Bayea, Germany)와 대사촉진제(Catosal, Bayer, Germany)를 4일간 추가로 근육주사하여 관리하였다. 그러나 한 마리가 수술 몇 일 후 죽어서 최종적으로 9마 리를 실험에 사용하였다. 10 일 후 앞서 설명한 바와 동일 하게 마취 후 수술 부위를 절개하여 임플란트 고정체가 식립된 부위를 노출시켜, 식립할 때와 같은 torque gauge 를 이용하여 제거회전력(removal torque, RTQ)을 측정 한 후, 토끼는 동물실험윤리에 따라 희생하였다.

\section{4. 표면분석}

\section{1) 표면형태 분석}

두 임플란트 그룹의 표면형태를 알아보기 위해 Field emission-scanning electron microscopy (FE-SEM, Hitachi SU8220, Tokyo, Japan)을 사용하여 2000배율로 촬영을 시행하였다.

2) 표면 거칠기(Surface roughness) 측정

표면 거칠기 측정은 $\mathrm{RSa}$ (average surface roughness) 와 RSq (mean root square of the surface)를 Confocal laser scanning microscopy (Carl Zeiss, LSM 700, Oberkochen, Germany)로 측정하였고, 시편의 3 군데를 임의로 선택하여 측정 후 평균값을 사용하였다.

\section{3) 표면 성분분석}

두 그룹의 임플란트 표면의 성분분석을 위해서 Energy dispersive X-ray Spectroscopy (EDS) 및 Raman microscope (DXR ${ }^{\mathrm{TM}}$ SmartRaman, ThermoScientific, Madison, USA)로 Raman 분광분석을 시행하였다.

\section{5. 통계분석}

두 그룹의 통계분석은 독립표본 T-test 및 Two-way ANOVA를 사용하였고, SPSS 22.0 (SPSS Inc., Chicago, $\mathrm{USA}$ )를 이용해 분석하였다.

\section{결과}

\section{1. 식립회전력 및 제거회전력}

임플란트 고정체 식립 후 10 마리 토끼 중 1마리가 죽 어서 총 9마리의 토끼에서 제거회전력을 측정하였다. 식 립회전력은 죽은 1 마리 토끼에서 측정된 값은 제외하였 으며, $\mathrm{RBM}+\mathrm{HCl}$ 그룹은 $14.06 \pm 10.57 \mathrm{~N} \cdot \mathrm{cm}, \mathrm{RBM}$ $+\mathrm{HCl}+\mathrm{Sal}$ 그룹은 $13.52 \pm 1.366 \mathrm{~N} \cdot \mathrm{cm}$ 로 측정되었다. 제거회전력은 $\mathrm{RBM}+\mathrm{HCl}$ 그룹은 $17.08 \pm 1.763 \mathrm{~N} \cdot \mathrm{cm}$, $\mathrm{RBM}+\mathrm{HCl}+\mathrm{Sal}$ 그룹은 $19.12 \pm 1.490 \mathrm{~N} \cdot \mathrm{cm}$ 로 측정 되었다. 독립검정 T-test를 이용한 통계분석에서 RBM $+\mathrm{HCl}$ 그룹에서 식립회전력과 제거회전력 사이에는 유 의미한 차이가 없었으나, $\mathrm{RBM}+\mathrm{HCl}+\mathrm{Sal}$ 그룹에서 는 식립회전력과 제거회전력 사이에 유의미한 차이를 보 였다 $(P=0.014<0.05)$ (Table 1). 또한 임플란트 고정체 의 종류와 식립 및 제거시의 토크값을 분석한 Two-way ANOVA 통계분석에서 식립시와 제거시의 토크값에서 통계적으로 유의미한 차이를 보였다 $(P=0.007<0.05)$ (Table 2).

\section{2. 표면형태}

FE-SEM을 이용하여 2,000배율로 표면을 확대하여 촬 영한 결과 두 임플란트 표면 모두 표면 전체에 걸쳐서 불 규칙한 크기의 다공성구조를 보였다(Fig. 1).

\section{3. 표면거칠기}

Confocal laser scanning microscopy를 사용한 표면거 칠기 측정결과 $\mathrm{RBM}+\mathrm{HCl}$ 그룹의 $\mathrm{RSa}$ 값은 평균 0.690 $\pm 0.055 \mu \mathrm{m}, \mathrm{RSq}$ 값은 평균 $0.869 \pm 0.073 \mu \mathrm{m}$ 로 측정되 었고, $\mathrm{RBM}+\mathrm{HCl}+\mathrm{Sal}$ 그룹의 $\mathrm{RS}$ 값은 평균 $0.897 \pm$ $0.047 \mu \mathrm{m}, \mathrm{RSq}$ 값은 평균 $1.153 \pm 0.077 \mu \mathrm{m}$ 로 측정되었 다(Fig. 2). 
Table 1. Comparison of $\mathrm{RBM}+\mathrm{HCl}$ group and $\mathrm{RBM}+\mathrm{HCl}+$ Sal group by independent two-sample T-test

\begin{tabular}{lccc}
\hline & $\mathrm{RBM}+\mathrm{HCl}$ & $\mathrm{RBM}+\mathrm{HCl}+\mathrm{Sal}$ & $P$ value \\
\hline Insertion torque $(\mathrm{ITQ}, \mathrm{N} \cdot \mathrm{cm})$ & $14.06 \pm 1.357$ & $13.52 \pm 1.366$ & 0.785 \\
Removal torque $(\mathrm{RTQ}, \mathrm{N} \cdot \mathrm{cm})$ & $17.08 \pm 1.763$ & $19.12 \pm 1.490$ & 0.389 \\
$\mathrm{P}$ value & 0.193 & $0.014 *$ & \\
\hline
\end{tabular}

*: $P<0.05$.

RBM, resorbable blasting media; $\mathrm{HCl}$, hydrogen chloride; Sal, normal saline.

Table 2. Comparison of $\mathrm{RBM}+\mathrm{HCl}$ group and $\mathrm{RBM}+\mathrm{HCl}+$ Sal group by two-way ANOVA

\begin{tabular}{|c|c|c|c|c|c|}
\hline & $\mathrm{df}$ & SS & MS & $\mathrm{F}$ & Sig \\
\hline \multicolumn{6}{|l|}{ Torque value } \\
\hline Type of fixture $(\mathrm{RBM}+\mathrm{HCl}$ vs $\mathrm{RBM}+\mathrm{HCl}+\mathrm{Sal})$ & 1 & 5.138 & 5.138 & 0.253 & 0.619 \\
\hline Time (Insertion vs Remove) & 1 & 167.271 & 167.271 & 8.231 & $0.007 *$ \\
\hline Type of fixture $*$ Time & 1 & 14.951 & 14.951 & 0.736 & 0.397 \\
\hline
\end{tabular}

$*: P<0.05$.

RBM, resorbable blasting media; $\mathrm{HCl}$, hydrogen chloride; Sal, normal saline.
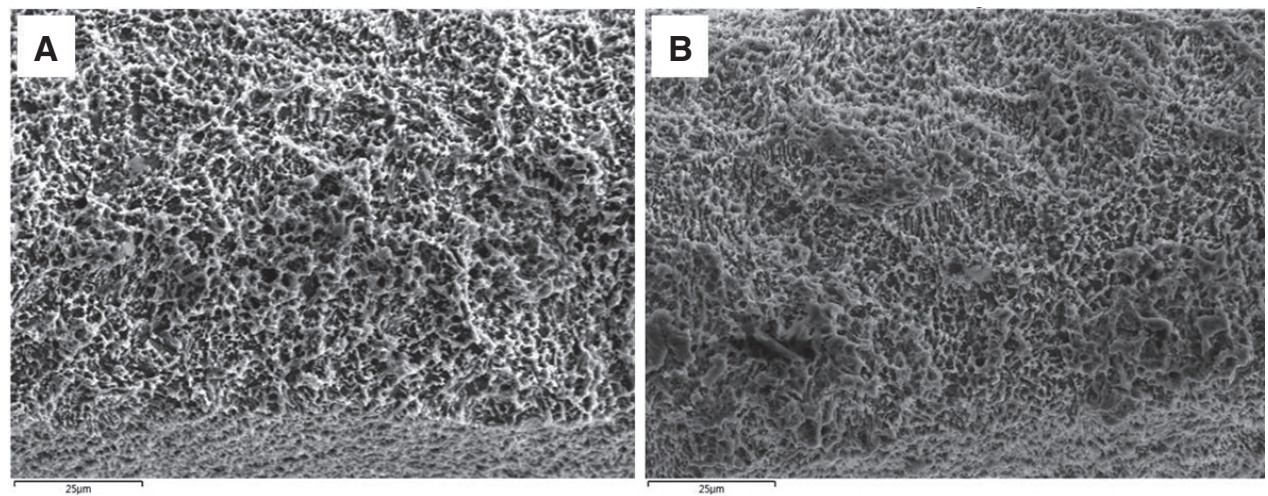

Fig. 1. $\mathrm{FE}-\mathrm{SEM}$ images of $\mathrm{RBM}+\mathrm{HCl}$ group and $\mathrm{RBM}+\mathrm{HCl}+$ Sal group $(\times 2,000)$ magnification. $(\mathrm{A}) \mathrm{RBM}+\mathrm{HCl}$ group, $(\mathrm{B})$ $\mathrm{RBM}+\mathrm{HCl}+$ Sal group.

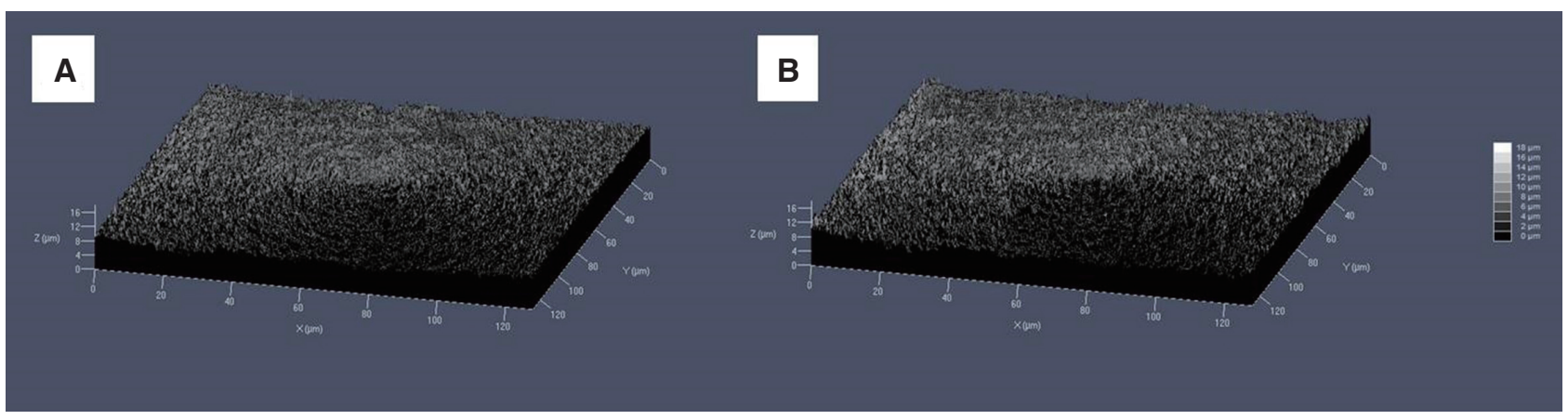

Fig. 2. Surface roughness images. (A) $\mathrm{RBM}+\mathrm{HCl}$ group, (B) $\mathrm{RBM}+\mathrm{HCl}+$ Sal group. 


\section{4. 표면 성분분석}

EDS 분석에서 두 그룹 모두 Ti와 O가 가장 많은 비율 로 검출되었고, $\mathrm{RBM}+\mathrm{HCl}+\mathrm{Sal}$ 그룹의 경우 추가적 으로 $\mathrm{Na}$ 과 $\mathrm{Cl}$ 이 검출되었다(Fig. 3, 4). Raman 분석에서 는 티타늄 임플란트의 표면을 덮고있는 $\mathrm{TiO}_{2}$ 막을 나타 내는 특징적인 peak 값을 보여주었으나, 두 그룹간에 특 별한 차이는 보이지 않았다(Fig. 5).

\section{고찰}

Branemark 등은 치과용 티타늄 임플란트와 주변골과 의 골유착 개념을 주장하였고, 현재까지도 이에 근거하 여 연구와 발전을 거듭하고 있다. ${ }^{14}$ 이러한 골유착의 정 도를 정량적으로 측정하는 방식으로 1988년도 Carlsson 등이 임플란트와 골사이의 결합을 파괴하기 위한 전단력 을 측정하는 방식으로 제거회전력을 이용하였다. ${ }^{15}$ 또 제 거회전력을 측정하는 시기도 골유착 정도를 가늠하는데

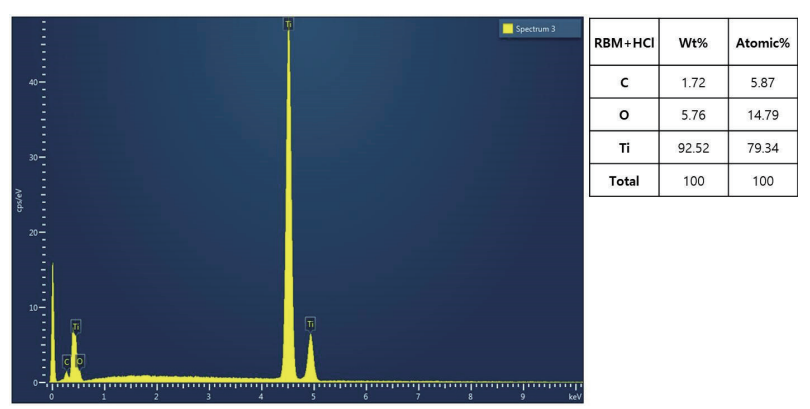

Fig. 3. EDS analysis of RBM $+\mathrm{HCl}$ group. RBM, resorbable blasting media; $\mathrm{HCl}$, hydrogen chloride.
중요한 요소이다. Albrektsson 등은 인간에서 임플란트 와 골과의 직접적인 결합을 유지하기 위해서는 임플란트 식립 후 3 - 4 개월의 시간이 필요하다고 하였다. ${ }^{16}$ 하지만 임플란트 식립 후 빠른 골유착이 임플란트의 성공에 중 요한 요소이다. 4주 후 산처리한 임플란트의 제거회전력 을 측정한 실험과 이를 토대로 임플란트 식립 후 6주에 보철물을 장착한 임상연구에서 3년간 임플란트의 성공 률이 $99 \%$ 에 이르는 연구가 있었다. ${ }^{17,18}$ 또 토끼를 이용한 실험에서 사람에서의 3 - 4개월의 치유기간이 토끼의 6주 간의 치유기간과 비슷한 결과를 나타낸다고 하였고, ${ }^{19}$ 사 람에서 임플란트의 조기부하(early loading)가 가능한 기 간을 임플란트 식립 후 1 - 8 주로 정하고 있다. ${ }^{20,21}$ 따라서 본 실험에서는 초기 골결합력을 측정하는데 필요한 기간 을 임플란트 식립 후 10 일로 정하였다. RTQ 값이 RBM $+\mathrm{HCl}$ 그룹은 $17.08 \pm 1.763 \mathrm{~N} \cdot \mathrm{cm}, \mathrm{RBM}+\mathrm{HCl}+\mathrm{Sal}$ 그룹은 $19.12 \pm 1.490 \mathrm{~N} \cdot \mathrm{cm}$ 로 측정되었고, 식립시와 제 거시에 회전력을 통계분석한 결과도 둘 사이에 유의미한 차이를 나타냈다(Table 2). 또한 이전의 실험에서 식립 한

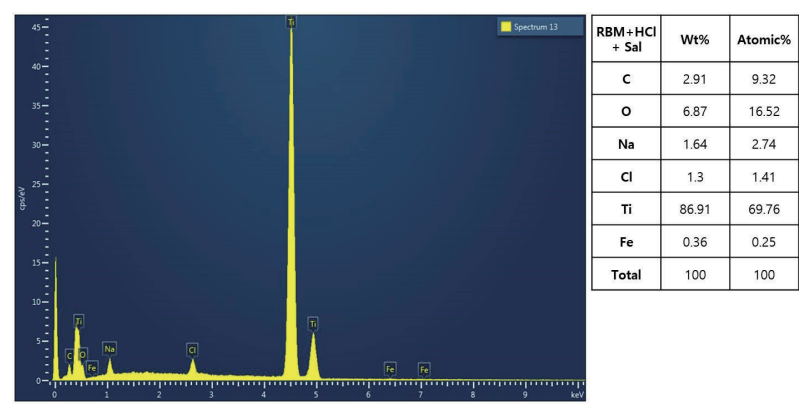

Fig. 4. EDS analysis of $\mathrm{RBM}+\mathrm{HCl}+$ Sal group. RBM, resorbable blasting media; $\mathrm{HCl}$, hydrogen chloride; Sal, normal saline.

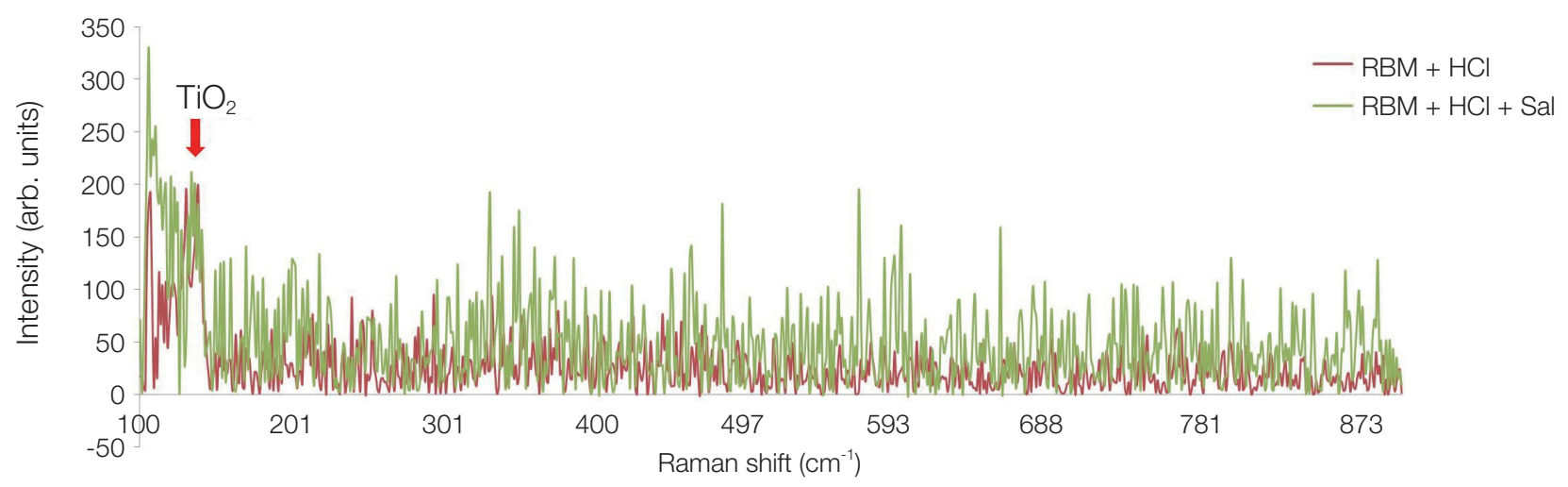

Fig. 5. Raman spectroscopy analysis of $\mathrm{RBM}+\mathrm{HCl}$ implant and $\mathrm{RBM}+\mathrm{HCl}+$ Sal group. RBM, resorbable blasting media; $\mathrm{HCl}$, hydrogen chloride; Sal, normal saline. 
달 후 토끼에서 측정된 제거회전력인 $20-30 \mathrm{~N} \cdot \mathrm{cm}$ 과 비 교해 본다면 짧은 기간에 높은 골결합력을 나타냈다고 할 수 있다. ${ }^{15}$

Buser 등에 의한 연구에서 높은 친수성을 가지는 임 플란트 표면이 그렇지 않은 경우와 비교하여 더 좋은 체 액, 세포 및 조직과의 반응을 보였고, 이를 일반적인 SLA 표면처리한 임플란트와 생리식염수에 적신 SLA표면처 리한 임플란트와의 BIC (bone-to-implant contact)를 통 해 비교하여 보여준 바 있다..$^{22}$ 이와 비슷하게 본 실험도 $\mathrm{RBM}$ 표면처리 후 산처리 및 생리식염수 에 적신 경우에 더 높은 제거회전력을 보여주었고, 생리식염수에 적시는 것이 초기 골결합에 유리하게 작용할 것이라고 생각할 수 있다.

FE-SEM으로 표면을 촬영한 사진에서 두 그룹 모두 불규칙한 다공성의 표면형태를 보였으나(Fig. 1), 표면 거칠기를 측정하였을 때, $\mathrm{RBM}+\mathrm{HCl}+\mathrm{Sal}$ 그룹에서 더 높은 RSq 값을 나타냈다. Webb 등에 의하면 거친표 면의 임플란트 표면에서 발생한 세포들이 osteocalcin과 alkaline phosphate를 더 많이 생산하고, 조골세포의 분 화를 돕는다고 하였다. ${ }^{23}$ 이론적으로 이상적인 표면은 깊 이 약 $1.5 \mu \mathrm{m}$, 직경 약 $4.0 \mu \mathrm{m}$ 의 반구형 소와형태라고 하였다. ${ }^{24}$ 그렇다고 너무 거친 임플란트 표면은 임플란 트 주위염을 증가시키는 원인이 되며, 적절한 표면거칠 기는 $1-2 \mu \mathrm{m}$ 라고 보고되기도 했다. ${ }^{25}$ 다른 여러 연구문 헌들에서도 높은 제거회전력과 $\mathrm{BIC}$ 를 보이는 적절한 표 면 거칠기를 $0.5-2.0 \mu \mathrm{m}$ 로 보고하고 있다. ${ }^{26}$ 본 실험에서 도 $\mathrm{RBM}+\mathrm{HCl}$ 그룹과 비교하여 높은 제거회전력을 보 인 $\mathrm{RBM}+\mathrm{HCl}+\mathrm{Sal}$ 그룹에서 반구형 소와형태의 다공 성의 표면과 평균 $1.153 \pm 0.077 \mu \mathrm{m}$ 의 $\mathrm{RSq}$ 를 보임으로 써, 앞선 연구들과 같은 결과를 나타내고 있다. 한가지 의 문스러운 점은 다만 실험군은 생리식염수에 적시는 추가 적인 절차만 거쳤을 뿐인데, 어떠한 이유로 표면의 거칠 기가 증가하게 된 것이지 짚어볼 필요가 있다. $\mathrm{EDS}$ 에서 보여주는 표면성분분석에서는 생리식염수에 적신 그룹 에서 그렇지 않은 그룹과 비교하여 $\mathrm{Ti}, \mathrm{O}$ 원소의 성분 비 율은 비슷하나, $\mathrm{Na}$ 과 $\mathrm{Cl}$ 성분이 검출되었다. 이는 생리식 염수 용액 내에 포함된 이온들이 임플란트의 표면에 접 착 또는 결합하여 나타난 결과로 생각된다. 이를 확인하 기 위해서 Raman 분광분석으로 임플란트 표면을 구성하 는 원소들의 결합에 관해서 확인해보면 티타늄 임플란트 의 표면을 덮고있는 $\mathrm{TiO}_{2}$ 막을 나타내는 peak는 쉽게 관 찰할 수 있었으나, ${ }^{27}$ 이외에 특징적으로 다른 물질을 구
분할 수 있는 peak 는 찾아보는 것이 어려웠다. 생리식염 수에 적신 경우 대조군과 비교하여 실험군의 임플란트 표면을 더 거칠게 만든 원인이 임플란트 표면의 성분들이 생리식염수에 용해되면서 표면의 거칠기를 증가시킨 것 은 아닌지, 어떠한 다른 원인이 있는지 추가적인 실험이 필요할 것으로 생각된다.

산처리한 임플란트의 경우 수소 취화(hydrogen embrittlement) 현상으로 티타늄 표면의 성질을 약화시키 고, 미소균열을 만들어 피로저항을 감소시킨다는 연구 결과가 있다. ${ }^{28}$ 본 실험에서는 표면 오염원으로 작용하지 않는 sandblasting 물질로 RBM을 사용하여 표면을 거칠 게 한 후, 안정적이고 균일한 $\mathrm{TiO}_{2}$ 표면을 만들고, 추가 적으로 잔류할 수 있는 오염원들을 제거하기 위해서 염 산을 이용해 산처리하는 방식을 사용하였다. 거기에 표 면 친수성을 증가시킬 수 있는 방법으로 생리식염수에 적시는 추가적인 표면처리를 더하였고, 결과적으로 만족 할만한 제거회전력과 적절한 표면처칠기를 측정할 수 있 었다. 하지만 산처리에 의한 임플란트 표면 약화를 알아 보기 위해서는 더 긴 식립기간과 적절한 식립기간마다 이 를 측정하는 추가적인 실험이 필요할 것이다.

\section{결론}

티타늄 임플란트에서 RBM 표면처리 후 산처리 및 생 리식염수에 적신 임플란트가 RBM 표면처리 후 산처리 한 임플란트 보다 초기 골 결합력 및 표면거칠기가 높게 측정되어 두 그룹 사이에 초기 골 결합력에 차이가 없다 는 귀무가설은 기각되었다. RBM 표면처리 후 산처리 및 생리식염수에 적신 임플란트의 식립기간을 더 길게 하여 산처리에 의한 영향에 대해서 추가적으로 평가해본다면 더욱 좋을 것으로 생각된다.

\section{ORCID}

Sung-am Cho https://orcid.org/0000-0002-8315-7833

\section{References}

1. Sullivan DY, Sherwood RL, Mai TN. Preliminary results of a multicenter study evaluating a chemically enhanced surface for machined commercially pure titanium implants. J Prosthet Dent 1997;78:379-86.

2. Mauceri N, Melilli D. Surface treatments for tita- 
nium implants. Int J Clin Dent 2015;8:139-49.

3. Svanborg LM, Andersson M, Wennerberg A. Surface characterization of commercial oral implants on the nanometer level. J Biomed Mater Res B Appl Biomater 2010;92:462-9.

4. Lazzara RJ, Testori T, Trisi P, Porter SS, Weinstein RL. A human histologic analysis of osseotite and machined surfaces using implants with 2 opposing surfaces. Int J Periodontics Restorative Dent 1999; 19:117-29.

5. Cooper LF. A role for surface topography in creating and maintaining bone at titanium endosseous implants. J Prosthet Dent 2000;84:522-34.

6. Wennerberg A, Albrektsson T. Effects of titanium surface topography on bone integration: a systematic review. Clin Oral Implants Res 2009;20 Suppl 4:172-84.

7. Le Guéhennec L, Soueidan A, Layrolle P, Amouriq Y. Surface treatments of titanium dental implants for rapid osseointegration. Dent Mater 2007;23: 844-54.

8. Bagno A, Di Bello C. Surface treatments and roughness properties of Ti-based biomaterials. J Mater Sci Mater Med 2004;15:935-49.

9. Piattelli M, Scarano A, Paolantonio M, Iezzi G, Petrone G, Piattelli A. Bone response to machined and resorbable blast material titanium implants: an experimental study in rabbits. J Oral Implantol 2002;28:2-8.

10. Müeller WD, Gross U, Fritz T, Voigt C, Fischer P, Berger G, Rogaschewski S, Lange KP. Evaluation of the interface between bone and titanium surfaces being blasted by aluminium oxide or bioceramic particles. Clin Oral Implants Res 2003;14:349-56.

11. Davies JE. Mechanisms of endosseous integration. Int J Prosthodont 1998;11:391-401.

12. Giavaresi G, Fini M, Cigada A, Chiesa R, Rondelli G, Rimondini L, Torricelli P, Aldini NN, Giardino R. Mechanical and histomorphometric evaluations of titanium implants with different surface treatments inserted in sheep cortical bone. Biomaterials 2003; 24:1583-94.

13. Zhao G, Schwartz Z, Wieland M, Rupp F, GeisGerstorfer J, Cochran DL, Boyan BD. High surface energy enhances cell response to titanium substrate microstructure. J Biomed Mater Res A 2005;74:4958.

14. Brånemark PI, Adell R, Breine U, Hansson BO, Lindström J, Ohlsson A. Intra-osseous anchorage of dental prostheses. I. Experimental studies. Scand J Plast Reconstr Surg 1969;3:81-100.

15. Carlsson L, Röstlund T, Albrektsson B, Albrektsson T. Removal torques for polished and rough itanium implants. Int J Oral Maxillofac Implants 1988;3:214.

16. Albrektsson T, Brånemark PI, Hansson HA, Lindström J. Osseointegrated titanium implants. Requirements for ensuring a long-lasting, direct boneto-implant anchorage in man. Acta Orthop Scand 1981;52:155-70.

17. Buser D, Nydegger T, Oxland T, Cochran DL, Schenk RK, Hirt HP, Snétivy D, Nolte LP. Interface shear strength of titanium implants with a sandblasted and acid-etched surface: a biomechanical study in the maxilla of miniature pigs. J Biomed Mater Res 1999;45:75-83.

18. Roccuzzo M, Wilson T. A prospective study evaluating a protocol for 6 weeks' loading of SLA implants in the posterior maxilla: one year results. Clin Oral Implants Res 2002;13:502-7.

19. Albrektsson T, Brånemark PI, Eriksson A, Lindström J. The preformed autologous bone graft. An experimental study in the rabbit. Scand J Plast Reconstr Surg 1978;12:215-23.

20. Esposito M, Grusovin MG, Maghaireh H, Worthington $\mathrm{HV}$. Interventions for replacing missing teeth: different times for loading dental implants. Cochrane Database Syst Rev 2013 Mar 28;(3): CD003878.

21. Sanz-Sánchez I, Sanz-Martín I, Figuero E, Sanz M. Clinical efficacy of immediate implant loading protocols compared to conventional loading depending on the type of the restoration: a systematic review. Clin Oral Implants Res 2015;26:964-82.

22. Buser D, Broggini N, Wieland M, Schenk RK, Denzer AJ, Cochran DL, Hoffmann B, Lussi A, Steinemann SG. Enhanced bone apposition to a chemically modified SLA titanium surface. J Dent Res 2004;83:529-33.

23. Webb K, Hlady V, Tresco PA. Relative impor- 
tance of surface wettability and charged functional groups on NIH 3T3 fibroblast attachment, spreading, and cytoskeletal organization. J Biomed Mater Res 1998;41:422-30.

24. Hansson S, Norton M. The relation between surface roughness and interfacial shear strength for bone-anchored implants. A mathematical model. J Biomech 1999;32:829-36.

25. Albrektsson T, Wennerberg A. The impact of oral implants - past and future, 1966-2042. J Can Dent Assoc 2005;71:327.
26. Shalabi MM, Gortemaker A, Van't Hof MA, Jansen JA, Creugers NH. Implant surface roughness and bone healing: a systematic review. J Dent Res 2006; 85:496-500.

27. Choi HC, Jung YM, Kim SB. Size effects in the Raman spectra of $\mathrm{TiO}_{2}$ nanoparticles. Vib Spectrosc 2005;37:33-8.

28. Yokoyama K, Ichikawa T, Murakami H, Miyamoto Y, Asaoka K. Fracture mechanisms of retrieved titanium screw thread in dental implant. Biomater 2002;23:2459-65. 


\section{Resorbable blasting media 및 산처리한 임플란트의 제거회전력에 생리식염수를 적시는 것이 미치는 영향}

권재욱, 조성암*

경북대학교 치과대학 치과보철학교실

목적: Resorbable blasting media (RBM) 표면처리 후 산처리한 티타늄 임플란트와 동일한 표면처리 후 생리식염수에 적 신 티타늄 임플란트에서 생리식염수에 적신 경우 초기 골유착에 미치는 영향을 제거회전력 및 표면분석을 통해서 알아보 고자 하였다.

연구 재료 및 방법: 대조군은 RBM 표면처리 후 산처리된 임플란트 $(\mathrm{RBM}+\mathrm{HCl})$ 이고, 실험군은 대조군과 동일한 표면처 리 후 생리식염수에 2주간 적신 임플란트 $(\mathrm{RBM}+\mathrm{HCl}+\mathrm{Sal})$ 이다. 토끼 10 마리의 좌우측 경골에 각각 대조군 및 실험군 임플란트를 식립하고, 동시에 식립회전력(ITQ)을 측정하였다. 10 일 후 임플란트 식립부위를 노출시켜 제거회전력(RTQ) 을 측정하였다. 실험에 사용된 임플란트 시편의 표면분석을 위해 field emission-scanning electron microscopy (FESEM), energy dispersive X-ray Spectroscopy (EDS), 표면거칠기 측정 및 Raman 분광분석을 시행하였다.

결과: RBM 표면처리 및 산처리하여 생리식염수에 적신 티타늄 임플란트에서 대조군에 비해 높은 제거회전력을 나타냈 으며, 통계적으로 유의미한 값을 보였다 $(P=0.014<0.05)$. 표면거칠기는 실험군에서 더 높은 거칠기를 나타냈다.

결론: 티타늄 임플란트에 RBM 표면처리 및 산처리 후 생리식염수에 적신 것이 생리식염수를 적시지 않은 것 보다 초기 골유착을 향상시키는 것으로 생각된다.

(구강회복응용과학지 2018;34(1):1-9)

주요어: 임플란트; 수산화인회석; 산 부식; 염화나트륨; 토끼

*교신저자: 조성암

(41940)대구광역시 중구 달구벌대로 2175 경북대학교 치의학전문대학원 치과보철학교실

Tel: 053-600-7672 | Fax: 053-427-0778 | E-mail: sungamcho@gmail.com

접수일: 2017년 7월 29일 | 수정일: 2017년 8월 21일 | 채택일: 2017년 8월 23일 